\title{
АСПЕКТИ ІНТРОДУКЦІЇ ПРЕДСТАВНИКІВ РОДУ ROSA L. У КРЕМЕНЕЦЬКОМУ БОТАНІЧНОМУ САДУ
}

\begin{abstract}
Одним із важливих напрямів науково-дослідних робіт у галузі інтродукції рослин є створення, вивчення, збагачення $\mathrm{i}$ збереження генофонду рослинного царства. Види і сорти роду Rosa здавна приваблюють увагу дослідників завдяки їх широкому використанню у декоративному садівництві та промисловому квітникарстві. Наведено результати з інтродукції представників роду Rosa в Україні. Колекція троянд Кременецького ботанічного саду на 2017 р. нараховує 28 сортів, що входять до 5 садових груп (чайно-гібридні, мініатюрні, паркові, виткі, флорибунда). Інтродукційне вивчення проведено 3 урахуванням еколого-біологічних та декоративних особливостей троянд. За абіотичними екологічними факторами сорти троянд належать до факультативних геліофітів, мезоксерофітів, мезотрофів. Згідно з розподілом сортів за садовими групами найбільше у колекції сортів троянд, що належать до чайно-гібридної - 10 видів $(35,7 \%)$ від усієї колекції, найменш численною $\epsilon$ група паркових - 1 (3,5 \%). За результатами фенологічних спостережень у період з 2012 по 2016 рр. за 28 видами, які зростають на колекційній ділянці ботанічного саду, встановлено, що більшість видів колекції цвітуть та плодоносять щороку.

Ключові слова: інтродукція; сорт; троянда; ботанічний сад; Rosa L.
\end{abstract}

Вступ. Аналіз сучасного стану квітникарства переконливо свідчить про те, що в багатьох країнах світу це важлива галузь економіки та експорту, з чітко вираженою тенденцією до подальшого розвитку виробництва, зовнішньої торгівлі квітами.

В Україні асортимент декоративних рослин, які сьогодні використовують в озелененні і які потенційно можна запропонувати споживачеві, ще надзвичайно бідний. Одним із шляхів вирішення цієї проблеми $\epsilon$ інтродукція нових видів, що охоплює їх пошук і науково обгрунтований добір за результатами попереднього оцінювання, інтродукційне випробування в нових умовах.

Серед найперспективніших для інтродукції квітниково-декоративних рослин - види та сорти роду Rosa L. здавна приваблюють увагу дослідників завдяки їх значному економічному, соціальному і поліфункціональному значенню та різноманітним напрямам використання: у декоративному садівництві, промисловому квітникарстві, ефіроолійному виробництві, вітамінній промисловості.

Початок вивчення роду Rosa в Україні О. Л. Рубцова датує серединою XVIII ст. Щодо історії інтродукції троянд, то на території України ії розпочали значно раніше, ніж вважає О. Л. Рубцова, ймовірно, ще за часів Кримського ханства, про що свідчать спогади турецького гуманіста XVII ст. Е. Челебі (Yena, 2013). У монографiї О. А. Ткачука, О. О. Ткачук коротко охарактеризовано роботу з інтродукції та селекції троянд в Україні.
Автори наголошують, що важливу роботу з інтродукції троянд в Україні виконують: академічні сади Києва та Донецька, ботанічний сад ім. О. В. Фоміна, Кам'янецьПодільський ботанічний сад, дендропарки "Софіївка", "Тростянець", "Олександрія". Автори зазначають, що, окрім інтродукції, ботанічні сади проводять значну селекційну роботу з троянд (Rubtsova, Pylypchuk, 2007; Rubtsova, 2011).

Матеріал і методика дослідження. Інтродукційне вивчення проводили 3 урахуванням еколого-біологічних та декоративних особливостей троянд (Kucheriavyi, 2001; Mysnyk, 1976).

Ритми сезонного розвитку рослин досліджували згідно з "Методикою фенологічних спостережень" (Воiko et at., 2015), починаючи з березня та закінчуючи у листопаді. Результати цих досліджень занесено до журналу фенологічних спостережень, на основі яких виокремлено такі фази росту та розвитку кущів троянд: набубнявіння бруньок; початок розпускання бруньок; початок лінійного росту пагонів; розпускання листя; бутонізація; початок, масове та кінець цвітіння; зав'язування плодів; дозрівання плодів; кінець вегетації.

На колекційній ділянці проводили нерегулярний полив, міжрядний обробіток грунту, мульчування міжрядь, обрізування сухих решток, перекопування, пересаджування, розсаджування, весняний та осінній висів насіння. Для підживлення використовували аміачну селітру. Також проводили дворазове обприскування фун-

\section{Інформація про авторів:}

Ковальчук Ірина Олександрівна, канд. біол. наук, завідувач відділом. Email: irina_skoroplas2017@ukr.net Скакальська Ольга Іванівна, науктвий співробітник. Email: kovalchukolja@ukr.net

Гетьман Ярослава Анатолівна, технік. Email: kbs1@ukr.net

Цитування за ДСту: Ковальчук I. О., Скакальська О. І., Гетьман Я. А. Аспекти інтродукції представників роду Rosa L. y Кременецькому ботанічному саду. Науковий вісник НЛтУ України. 2018, т. 28, № 2. С. 72-76.

Citation APA: Kovalchuk, I. O., Skakal's'ka, O. I., \& Getman, Ya. A. (2018). Aspects of an Introduktion of Representatives of the Genus Rosa L. in the Kremenetsky Botanical Garden. Scientific Bulletin of UNFU, 28(2), 72-76. https://doi.org/10.15421/40280213 
гіцидами (розчином йоду, оцтової кислоти та розчином господарського мила. Отримані результати науководослідної роботи опрацьовано на комп'ютері з використанням програм Microsoft Office World, Microsoft Excel 2003, 2007.

Результати дослідження та їх обговорення. Вплив абіотичних факторів потрібно враховувати не тільки під час вирощування рослин, але й для вирішення архітектурно-художніх завдань (Kucheriavyi, 2001). Саме тому важливого значення для збереження декоративного вигляду кущами набувають показники екостійкості. Чим стійкіші рослини до абіотичних факторів, тим вищий їхній рівень протидії різного роду фітопатогенам (Tkachuk, 1993).

Згідно 3 аналізом біоморфологічних показників (Klymenko et at, 1986; 1999; 2002; Takhtadzhian, 1987), y колекції переважають (табл. 1):

• кущі - 24 шт. (85,7 \%), нанофанерофіти - 25 шт. (89,2 \%) (за життєвими формами I. Г. Серебрякова та К. Раункієра);

- кущі групи $\mathrm{K}_{2}-15$ шт. (53,5 \%) (за С. Я. Соколовим);

- за щільністю (за Л. В. Хархотою) та формою крони - $\mathrm{Cl}$ 24 шт. (85,7 \%), та 18 шт. (64,2 \%) - сорти із прямостоячими пагонами.

Табл. 1. Біоморфологічні показники сортів троянд Кременецького ботанічного саду

\begin{tabular}{|c|c|c|c|c|c|c|}
\hline \multirow[b]{2}{*}{$\begin{array}{c}\text { № } \\
\text { 3/ח }\end{array}$} & \multirow[b]{2}{*}{ Назва сорту } & \multicolumn{5}{|c|}{ Характеристика виду (сорту) } \\
\hline & & 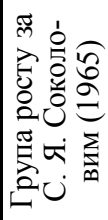 & 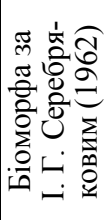 & 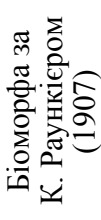 & 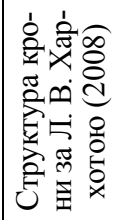 & 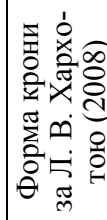 \\
\hline \multicolumn{7}{|c|}{ Група виткі } \\
\hline 1 & $\begin{array}{c}\text { Rosa x hybrid } \\
\text { hort. 'Wartburg' }\end{array}$ & $\mathrm{K}_{2}$ & $\mathrm{~K}$ & MPh & $\mathrm{Cl}$ & 4 \\
\hline 2 & 'Vohni majaka' & $\mathrm{K}_{2}$ & $\bar{K}$ & $\mathrm{NPh}$ & $\mathrm{Cl}$ & 4 \\
\hline 3 & 'New dawn' & $\mathrm{K}_{2}$ & K & $\mathrm{NPh}$ & $\mathrm{Cl}$ & 4 \\
\hline 4 & 'Veilchenblau' & $\mathrm{K}_{1}$ & $\bar{K}$ & NPh & $\mathrm{Cl}$ & 4 \\
\hline 5 & 'Ledy gay' & $\mathrm{K}_{2}$ & $\mathrm{~K}$ & $\mathrm{MPh}$ & $\mathrm{Cl}$ & 4 \\
\hline \multicolumn{7}{|c|}{ Група мініатюрні } \\
\hline 6 & 'Polka dot' & $\mathrm{K}_{1}$ & К-и & $\mathrm{NPh}$ & $\mathrm{Cd}$ & 3 \\
\hline 7 & 'Optima red' & $\mathrm{K}_{1}$ & К-и & $\mathrm{NPh}$ & $\mathrm{Cd}$ & 3 \\
\hline 8 & 'Pink fairy' & $\mathrm{K}_{1}$ & К-и & $\mathrm{NPh}$ & $\mathrm{Cd}$ & 3 \\
\hline 9 & 'Lydia' & $\mathrm{K}_{1}$ & К-и & $\mathrm{NPh}$ & $\mathrm{Cd}$ & 3 \\
\hline \multicolumn{7}{|c|}{ Група чайно-гібридні } \\
\hline 10 & 'Sophia loren' & $\mathrm{K}_{2}$ & $\mathrm{~K}$ & $\mathrm{NPh}$ & $\mathrm{Cl}$ & 7 \\
\hline 11 & 'Kardinal' & $\mathrm{K}_{1}$ & $\mathrm{~K}$ & NPh & $\mathrm{Cl}$ & 7 \\
\hline 12 & 'Anna' & $\mathrm{K}_{2}$ & $\mathrm{~K}$ & $\mathrm{NPh}$ & $\mathrm{Cl}$ & 7 \\
\hline 13 & 'Landora' & $\mathrm{K}_{2}$ & K & $\mathrm{NPh}$ & $\mathrm{Cl}$ & 7 \\
\hline 14 & 'Dam de couer' & $\mathrm{K}_{2}$ & K & $\mathrm{NPh}$ & $\mathrm{Cl}$ & 7 \\
\hline 15 & 'Uncle Walter' & $\mathrm{K}_{1}$ & $\bar{K}$ & $\mathrm{NPh}$ & $\mathrm{Cl}$ & 7 \\
\hline 16 & 'Royal dane' & $\mathrm{K}_{1}$ & $\bar{K}$ & $\mathrm{NPh}$ & $\mathrm{Cl}$ & 7 \\
\hline 17 & 'Dolce vita' & $\mathrm{K}_{2}$ & $\mathrm{~K}$ & $\mathrm{NPh}$ & $\mathrm{Cl}$ & 7 \\
\hline 18 & 'Ingrid Bergman' & $\mathrm{K}_{2}$ & $\mathrm{~K}$ & $\mathrm{NPh}$ & $\mathrm{Cl}$ & 7 \\
\hline 19 & 'Clear ocean' & $\mathrm{K}_{1}$ & $\mathrm{~K}$ & $\mathrm{NPh}$ & $\mathrm{Cl}$ & 7 \\
\hline \multicolumn{7}{|c|}{ Група паркові } \\
\hline 20 & 'Robusta' & $\mathrm{K}_{3}$ & $\mathrm{~K}$ & $\mathrm{MPh}$ & $\mathrm{Cl}$ & 3 \\
\hline \multicolumn{7}{|c|}{ Група флорибунда } \\
\hline 21 & 'Arthur Bell' & $\mathrm{K}_{1}$ & $\mathrm{~K}$ & $\mathrm{NPh}$ & $\mathrm{Cl}$ & 7 \\
\hline 22 & 'Queen Elizabeth' & $\mathrm{K}_{2}$ & $\mathrm{~K}$ & $\mathrm{NPh}$ & $\mathrm{Cl}$ & 7 \\
\hline 23 & 'Zheltos' & $\mathrm{K}_{1}$ & $\mathrm{~K}$ & NPh & $\mathrm{Cl}$ & 7 \\
\hline 24 & 'Fresia' & $\mathrm{K}_{1}$ & $\mathrm{~K}$ & $\mathrm{NPh}$ & $\mathrm{Cl}$ & 7 \\
\hline 25 & 'Iceberg' & $\mathrm{K}_{1}$ & $\mathrm{~K}$ & $\mathrm{NPh}$ & $\mathrm{Cl}$ & 7 \\
\hline 26 & 'Tom tom' & $\mathrm{K}_{1}$ & $\mathrm{~K}$ & $\mathrm{NPh}$ & $\mathrm{Cl}$ & 7 \\
\hline 27 & 'Lavaglut' & $\mathrm{K}_{1}$ & $\mathrm{~K}$ & NPh & $\mathrm{Cl}$ & 7 \\
\hline 28 & 'Allgold' & $\mathrm{K}_{2}$ & $\mathrm{~K}$ & $\mathrm{NPh}$ & $\mathrm{Cl}$ & 7 \\
\hline
\end{tabular}

Примітка: групи росту кущів (1-4 величина) за С. Я. Соколовим

(1965): $K_{1}$ - заввишки менше ніж 1 м; $K_{2}$ - заввишки $1-2$ м; $K_{3}$
- заввишки 2-3 м; $\mathrm{K}_{4}$ - заввишки понад 3 м; життєва форма за I. Г. Серебряковим (1962): К - кущ; К-и - кущики; біоморфа за К. Раункієром (1907): NPh - нанофанерофіти; MPh - мікрофанерофіти; щільність крони за Л. В. Хархотою (2008): Сd (лат. coma densa) - щільна, густа, компактна (просвіти до $50 \%$ ); $\mathrm{Cl}$ (лат. coma laxa) - пухка, рихла (просвіти більше 50 \%); форма крони за Л. В. Хархотою (2008): 1 - обернено яйцеподібна; 2 округла, куляста; 3 - розлога; 4 - витка; 5 - сланка; 6 - куполоподібна; 7 - із прямостоячими пагонами; 8 - неправильна, асиметрична; 9 - воронкоподібна.

За абіотичними екологічними факторами сорти троянд належать до факультативних геліофітів (геліофітністю), мезоксерофітів (гігрофітністю), мезотрофів (трофністю), морозостійких (термоморфністю). Згідно 3 розподілом сортів за садовими групами найбільше у колекції представлені сорти троянд, що належать до чайно-гібридної - 10 видів $(35,7 \%)$ від усієї колекції, найменш численна група паркових - 1 (3,5\%) (рис. 1).

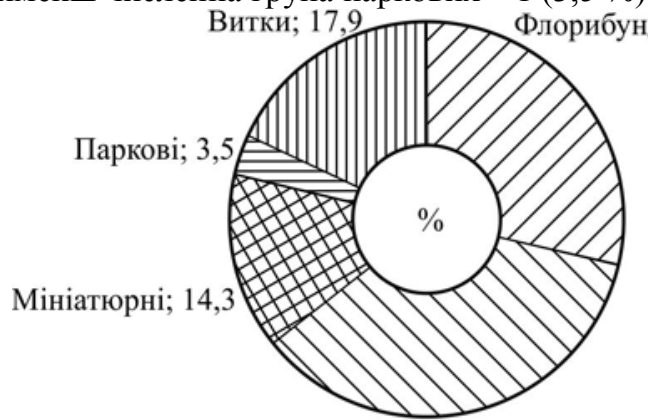

Чайногібридні; 35,7

Рис. 1. Спектр розподілу сортів троянд за садовими групами

На 2016 р. колекція троянд нараховує 28 сортів, що входять до 5 садових груп. Упродовж звітного періоду здійснювали поповнення колекції троянд шляхом збирання пропагул унаслідок обміну посадкового матеріалу з установами України (Кременецька обласна гуманітарно-педагогічна академія ім. Тараса Шевченка, Богоявленський монастир), а також з приватними особами. Колекцію було поповнено 32 новими сортами: 'Imperatrice Farah', 'Persian Yellow', 'Imperatrica', 'Black magic', 'William morris', 'Norita', 'Golden Silver', 'Bella perla', 'Aqua', 'Kerio' та ін. (рис. 2).

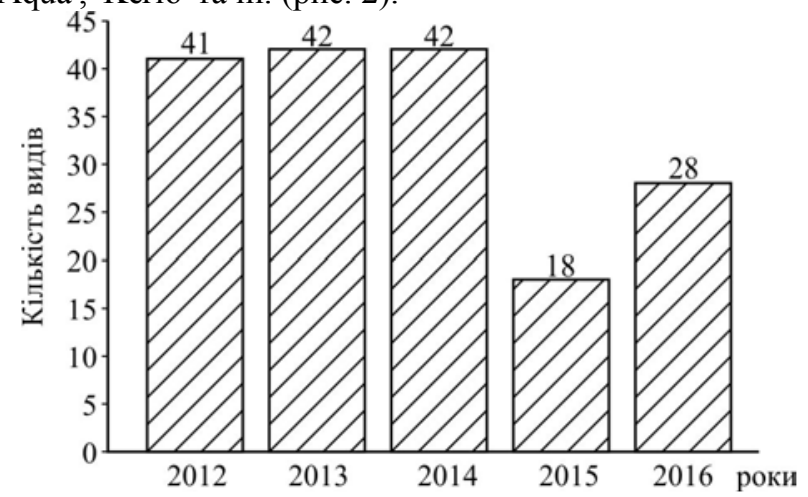

Рис. 2. Динаміка колекційного фонду (2012-2016 pp.)

За звітний період проводили інтродукційне вивчення біологічних, екологічних, адаптаційних особливостей сортів троянд та продовжено роботу над створенням розарію.

Фенологічні спостереження у ботанічних садах є одним 3 важливих напрямів науково-дослідної роботи. Основними завданнями фенологічних спостережень за рослинами є: встановлення сезонної динаміки їх росту; визначення особливостей сезонного ритму; визначення 
фенологічних індикаторів для різних сезонів року та фенопрогнозування.

Проведені фенологічні спостереження в період 3 2012 по 2016 рр. за 28 видами, які зростають на колекційній ділянці ботанічного саду, дали змогу встановити, що більшість видів, представлених у колекції, квітують щороку. 13 березня найпершими почали вегетацію (набубнявіння бруньок) 6 видів - 'Vohni majaka', 'Ledy gay', 'Sophia loren', 'Anna', а найпізніше фазу зафіксовано у 'Queen Elizabeth', 'Polka dot' - 31 березня.

Фаза "початок розпукування бруньок" найпершою настала 31 березня у 'New dawn', 'Sophia loren', 'Landora', 'Dam de couer', а найпізніше іiї зафіксовано 10 квітня у 'Polka dot', 'Arthur Bell', 'Queen Elizabeth'. Найперше фазу "початок лінійного росту" зафіксовано 6 квітня у таких видів: 'New dawn', 'Sophia loren', 'Landora', а найпізніше - у 'Wartburg', 'Veilchenblau', 'Arthur Bell', 'Anna' (22 квітня). Фазу "розпускання листя" найперше відзначено 17 квітня у 'New dawn', 'Landora', 'Dam de couer', a найпізніше 17 травня - y 'Sophia loren'.

Генеративний період настає у травні. Феноспектр сезонного розвитку сортів троянд показує, що ранній генеративний етап розвитку серед групи досліджених видів характерний для 'Wartburg', 'Arthur Bell'. Характерною особливістю видів $є$ розпускання генеративних бруньок та поява квітів. Тривалість цвітіння цих видів (від початку до кінця цвітіння) становить $7^{ \pm 3}$ дні.

Інші сорти троянд повністю проходять вегетаційний розвиток, який триває півтора-два місяці (березень, квітень та перша половина травня), а саме набубнявіння та розпускання бруньок, розпускання листя, ріст та розвиток системи пагонів і тільки у п'ятому (травні) та першій половині шостого місяця (червень) види входять у генеративну фазу. До видів, цвітіння яких відбувається у другій та третій декадах травня належать: 'Wartburg', 'Arthur Bell', 'Dam de couer'. У першій та другій декаді червня цвітуть види: 'Vohni majaka', 'New dawn', 'Polka dot', 'Kardinal', 'Anna', 'Landora'.

За метеорологічними даними в період березень квітень 2012, 2014 рр. температура повітря була в межах $+4-+16^{\circ} \mathrm{C}$, на відмінну від попередніх 2013, 2015 років температура повітря була в межах +4 $+8{ }^{\circ} \mathrm{C}$. Це зумовило ранне набубнявіння і розпускання вегетативних та генеративних бруньок. Тому фаза цвітіння у дорослих видів розпочалась на 5-12 днів раніше і тривала на 4-6 днів довше на відмінну від попередніх 2013, 2015 pp.

На основі отриманих даних створено спектр тривалості цвітіння (дні) сортів троянд (табл. 2, рис. 3).

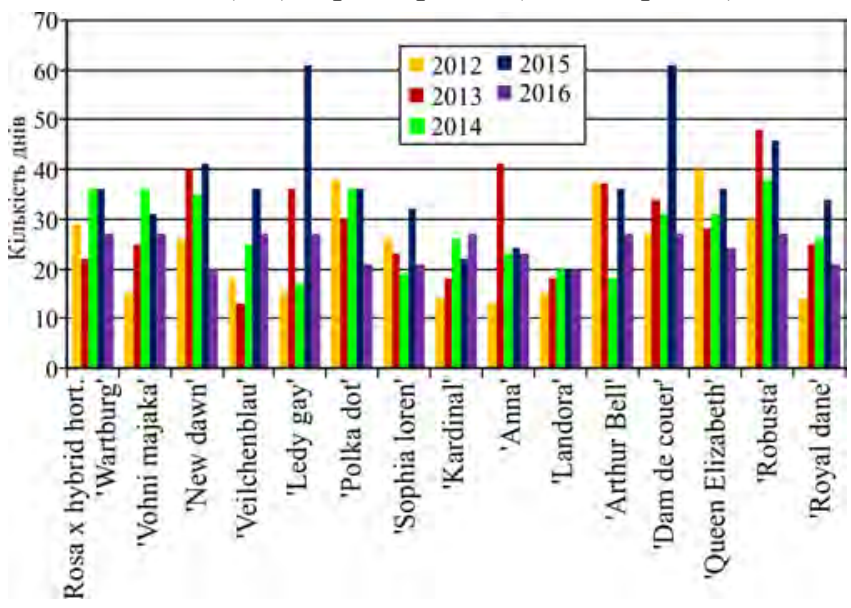

Рис. 3. Тривалість цвітіння сортів троянд

Табл. 2. Цвітіння сортів троянд у період з 2012 по 2016 рр.

\begin{tabular}{|c|c|c|c|c|c|c|c|c|c|c|c|c|}
\hline \multirow{2}{*}{$\begin{array}{c}\text { № } \\
3 / \Pi\end{array}$} & \multirow{2}{*}{ Назва виду } & \multicolumn{2}{|c|}{ Цвітіння 2012} & \multicolumn{2}{|c|}{ Цвітіння 2013} & \multicolumn{2}{|c|}{ Цвітіння 2014} & \multicolumn{2}{|c|}{ Цвітіння 2015} & \multicolumn{2}{|c|}{ Цвітіння 2016} & \multirow{2}{*}{$\begin{array}{c}\text { Середня три- } \\
\text { валість цві- } \\
\text { тіння (дні) } \\
\end{array}$} \\
\hline & & Поч. & Кін. & Поч. & Кін. & Поч. & Кін. & Поч. & Кін. & Поч. & Кін. & \\
\hline 1 & Rosa x hybrid hort. 'Wartburg' & 29.05 & 28.06 & 7.06 & 29.06 & 3.06 & 9.07 & 3.06 & 9.07 & 20.05 & 17.06 & $30^{ \pm 1}$ \\
\hline 2 & 'Vohni majaka' & 11.06 & 26.06 & 3.06 & 28.06 & 28.05 & 4.07 & 29.05 & 30.06 & 23.05 & 20.06 & $26^{ \pm 2}$ \\
\hline 3 & 'New dawn' & 14.06 & 10.07 & 18.06 & 28.07 & 19.06 & 24.07 & 19.06 & 30.07 & 10.06 & 30.06 & $32^{ \pm 2}$ \\
\hline 4 & 'Veilchenblau' & 21.06 & 9.07 & 19.06 & 2.07 & 2.06 & 27.06 & 3.06 & 9.07 & 20.05 & 17.06 & $23^{ \pm 1}$ \\
\hline 5 & 'Ledy gay' & 22.06 & 7.07 & 11.06 & 17.07 & 9.06 & 26.06 & 29.05 & 30.07 & 23.05 & 20.06 & $31^{ \pm 2}$ \\
\hline 6 & 'Optima red' & 14.06 & 10.07 & 18.06 & 18.07 & 28.05 & 4.07 & 29.05 & 30.06 & 23.06 & 20.07 & $30^{ \pm 1}$ \\
\hline 7 & 'Pink fairy' & 29.05 & 28.06 & 7.06 & 29.06 & 3.06 & 9.07 & 3.06 & 9.07 & 20.05 & 17.06 & $31^{ \pm 1}$ \\
\hline 8 & 'Lydia' & - & - & - & - & - & - & - & - & 10.07 & 3.08 & 23 \\
\hline 9 & 'Polka dot' & 18.06 & 26.07 & 19.06 & 19.07 & 17.06 & 23.07 & 17.06 & 23.07 & 10.06 & 1.07 & $33^{ \pm 1}$ \\
\hline 10 & 'Sophia loren' & 9.07 & 5.08 & 22.06 & 15.07 & 9.07 & 28.07 & 15.06 & 17.07 & 10.06 & 1.07 & $24^{ \pm 1}$ \\
\hline 11 & 'Uncle Walter' & 18.06 & 5.07 & 25.06 & 18.07 & 22.06 & 12.07 & 20.06 & 19.07 & 3.06 & 27.06 & $22^{ \pm 2}$ \\
\hline 12 & 'Dolce vita' & 18.06 & 2.07 & 17.06 & 12.07 & 16.06 & 12.07 & 17.06 & 23.07 & 10.06 & 1.07 & $24^{ \pm 1}$ \\
\hline 13 & 'Arthur Bell' & 29.05 & 6.07 & 7.06 & 14.07 & 22.06 & 10.07 & 3.06 & 9.07 & 20.05 & 17.06 & $31^{ \pm 1}$ \\
\hline 14 & 'Ingrid Bergman' & - & - & - & - & - & - & - & - & 10.07 & 3.08 & 23 \\
\hline 15 & 'Clear ocean' & - & - & - & - & - & - & - & - & 23.05 & 20.06 & 27 \\
\hline 16 & 'Kardinal' & 12.06 & 26.06 & 19.06 & 7.07 & 14.06 & 10.07 & 17.06 & 9.07 & 20.05 & 17.06 & $21^{ \pm 2}$ \\
\hline 17 & 'Anna' & 19.06 & 2.07 & 7.05 & 18.06 & 16.06 & 9.07 & 12.06 & 6.07 & 27.05 & 20.06 & $25^{ \pm 2}$ \\
\hline 18 & 'Landora' & 17.06 & 2.07 & 17.06 & 5.07 & 20.06 & 10.07 & 19.06 & 9.07 & 10.06 & 30.06 & $18^{ \pm 2}$ \\
\hline 19 & 'Zheltos' & - & - & - & - & - & - & - & - & 7.07 & 30.07 & 23 \\
\hline 20 & 'Fresia' & - & - & - & - & - & - & - & - & 4.07 & 30.07 & 26 \\
\hline 21 & 'Iceberg' & - & - & - & - & - & - & - & - & 11.07 & 8.08 & 27 \\
\hline 22 & 'Tom tom' & - & - & - & - & - & - & - & - & 11.07 & 4.08 & 23 \\
\hline 23 & 'Lavaglut' & - & - & - & - & - & - & - & - & 4.07 & 4.08 & 30 \\
\hline 24 & 'Allgold' & - & - & - & - & - & - & - & - & 11.07 & 8.08 & 27 \\
\hline 25 & 'Dam de couer' & 31.05 & 27.06 & 11.06 & 15.07 & 27.05 & 28.06 & 29.05 & 30.07 & 23.05 & 20.06 & $36^{ \pm 1}$ \\
\hline 26 & 'Queen Elizabeth' & 15.06 & 25.07 & 16.06 & 14.07 & 16.06 & 27.07 & 17.06 & 23.07 & 3.06 & 27.06 & $32^{ \pm 1}$ \\
\hline 27 & 'Robusta' & 5.06 & 5.07 & 11.06 & 29.07 & 11.06 & 27.07 & 29.05 & 30.07 & 5.06 & 20.06 & $39^{ \pm 2}$ \\
\hline 28 & 'Royal dane' & 18.06 & 2.07 & 17.06 & 12.07 & 16.06 & 12.07 & 19.06 & 23.07 & 17.06 & 25.07 & $24^{ \pm 2}$ \\
\hline
\end{tabular}


На спектрі відзначаємо тривалість цвітіння видів за кількістю днів у період з 2012 по 2016 рр. спостережень, а саме тривалі періоди зафіксовано у 2013, 2015 рр., через вищі температурні показники порівняно 3 попередніми роками. Відносно однакові терміни цвітіння (за кількістю днів) щороку відзначено у видів: 'Ledy gay', 'Dam de couer', 'Robusta' та ін. Найдовшу фазу цвітіння відзначено у видів: 'Robusta' $\left(39^{ \pm 2}\right)$, 'Dam de couer' $\left(36^{ \pm 1}\right)$, 'Polka dot' $\left(33^{ \pm 1}\right)$, найкоротшу - у видів: 'Landora' $\left(18^{ \pm 2}\right)$, 'Kardinal' $\left(21^{ \pm 2}\right)$, 'Veilchenblau' $\left(23^{ \pm 1}\right)$.

Період цвітіння сортів троянд у різні роки може зміщуватися від середніх дат залежно від погодних умов, але в черговості зацвітання залишається стабільність. Отримані результати фенологічних спостережень дали змогу поділити досліджуванні сорти троянд на феногрупи за термінами початку і кінця цвітіння (табл. 3).

Табл. 3. Розподіл сортів троянд за строками фенологічних сезонів

\begin{tabular}{|c|c|c|c|}
\hline $\begin{array}{c}\text { Фенологічний } \\
\text { сезон }\end{array}$ & Термін & $\begin{array}{l}\text { Кіль- } \\
\text { кість }\end{array}$ & \begin{tabular}{|c}
$\%$ до за- \\
гальної \\
кількості
\end{tabular} \\
\hline \multicolumn{4}{|c|}{ Початок вегетації } \\
\hline Ранньовесняні & I-III дек. березня & 28 & 100 \\
\hline Середньовесняні & I-II дек. квітня & - & - \\
\hline Пізньовесняні & $\begin{array}{c}\text { III дек. квітня - I } \\
\text { дек. травня }\end{array}$ & - & - \\
\hline \multicolumn{4}{|c|}{ Тривалість вегетації } \\
\hline Коротковегетуючі & до 150 днів & - & - \\
\hline Середньовегетуючі & 150-200 днів & - & - \\
\hline Довговегетуючі & понад 200 днів & 28 & 100 \\
\hline \multicolumn{4}{|c|}{ Час зацвітання } \\
\hline Ранньовесняні & $\begin{array}{c}\text { березень - поч. квіт- } \\
\text { ня }\end{array}$ & - & - \\
\hline Середньовесняні & $\begin{array}{c}\text { квітень - I пол. трав- } \\
\text { ня } \\
\end{array}$ & - & - \\
\hline Пізньовесняні & Травень & 12 & 43 \\
\hline Ранньолітні & I пол. червня & 8 & 28,4 \\
\hline $\begin{array}{c}\text { Ранньосередньо- } \\
\text { літні }\end{array}$ & $\begin{array}{c}\text { кін. червня - поч. } \\
\text { липня } \\
\end{array}$ & 3 & 10,6 \\
\hline Середньо літні & $\begin{array}{c}\text { кін. липня - поч. } \\
\text { серпня }\end{array}$ & 5 & 18 \\
\hline Пізньолітні & Серпень & - & - \\
\hline \multicolumn{4}{|c|}{ Тривалість цвітіння } \\
\hline Швидкоквітучі & до 10 днів & - & - \\
\hline $\begin{array}{l}\text { Швидкосередньок- } \\
\text { вітучі }\end{array}$ & 10-20 днів & 1 & 3,5 \\
\hline Середньоквітучі & 20-40 днів & 27 & 96,5 \\
\hline Довгоквітучі & 40-60 днів & - & - \\
\hline Тривалоквітучі & понад 60 днів & - & - \\
\hline
\end{tabular}

Групуючи види за термінами початку і кінця вегетації та цвітіння, з'ясовано, що за початком вегетації сорти троянд належать до групи ранньовесняні - 100 \%, за тривалістю вегетації: до групи довговегетуючих $100 \%$, за часом зацвітання переважає група пізньовесняні - $43 \%$, за тривалістю цвітіння - середньоквітучі $(96,5 \%)$.

Групуючи види троянд, можна створювати сад безперервного їх цвітіння в період із травня по серпень.
Найпершими вступили у фазу відмирання 20 жовтня 'Veilchenblau', 'Ledy gay', 'Sophia loren', найпізніше 7 листопада - 'Wartburg', 'Landora' та ін.

Отже, проведені феноспостереження впродовж 2012-2016 рр. показали, що період цвітіння троянд тривалий, він може зміщуватися від середніх дат, що пов'язано із змінами погодних умов, але в черговості зацвітання залишається стабільність. Відповідно до отриманих даних можна створювати композиційні елементи ландшафту.

Висновок. Результати проведених досліджень показують, що фенологічні фази розвитку рослин напряму залежать від едафічних та погодних умов території їх зростання. Установлено наявний взаємозв'язок між термінами цвітіння і кліматичними умовами. Найтриваліше цвітіння за вегетативний період мали 'Robusta' $\left(39^{ \pm 2}\right)$, 'Dam de couer' $\left(36^{ \pm 1}\right)$, 'Polka dot' $\left(33^{ \pm 1}\right)$. Серед досліджених інтродуцентів надзвичайну високу декоративність цвітіння мають 19 сортів ('Wartburg', 'New dawn', 'Ledy gay', 'Landora' та ін.), високу - 8 ('Vohni majaka', 'Polka dot','Optima red', 'Royal dane' та ін.), середню декоративність - 1 ('Veilchenblau').

\section{Перелік використаних джерел}

Boiko, R. V., Shcherbakova, O. F., Rubtsova, E. L., \& Chyzhankova, V. Y. (201). Metodycheskye rekomendatsyy po fenolohycheskym nabliudenyiam za povtorno tsvetushchymy rozamy. Kyev. 52 p. [in Russian].

Klymenko, Z. K. (2002). Sekretu vurashchyvanyia roz. Moscow: ZAO "Fyton +". 360 p. [in Russian].

Klymenko, Z. K., \& Rubtsova E. L. (1986). Rozy. Kataloh - spravochnyk. Naukova dumka. $580 \mathrm{p}$.

Klymenko, Z. K., Rubtsova, O. L., Skrybchenko, T. A., \& Zykova, V. K. (1999). Vytki troiandy v Ukraini. Introduktsiia roslyn, 3-4, 157160. [in Ukrainian].

Kucheriavyi, V. P. (2001). Ekolohiia. Lviv. 500 p. [in Ukrainian].

Mysnyk, H. E. (1976). Sroky y kharakter tsvetenyia derevev y kustarnykov. Kyiv. 390 p. [in Russian].

Rubtsova, O. L. (2011). Rosa L. v Ukraini: istoriia, napriamy doslidzhen, dosiahnennia ta perspektyvy. Abstract of Doctoral Dissertation for Biology Sciences (03.00.23 - History of biology). Natsionalnyi botanichnyi sad im. M. M. Hryshka NAN Ukrainy. Kyiv. 41 p. [in Ukrainian].

Rubtsova, O. L., Pylypchuk, V. F., Shumyk, M. I., \& Chyzhankova, V. I. (2007). Rekomendatsii $z$ pidboru, vyroshchuvannia $i$ vykorystannia parkovykh troiand u sadovykh kompozytsiiakh $\mathrm{m}$. Kyieva. Kyiv: Fitosotsiotsentr. 32 p. [in Ukrainian].

Takhtadzhian, A. L. (1987). Systema mahnolyofytov. Leningrad: Nauka. 440 p. [in Russian].

Tkachuk, O. A., \& Tkachuk, O. O. (1993). Troiandy. Dovidkovyi posibnyk. Kyiv: Vyshcha shkola. 207 p. [in Ukrainian].

Tkachyk, S. O. (Ed.) (2015). Metodyka provedennia ekspertyzy sortiv roslyn hrupy dekoratyvnykh, likarskykh ta efirooliinykh, lisovykh na prydatnist do poshyrennia v Ukraini (PSP). (2nd ed.). Vinnytsia: TOV "Nilan-LTD". 130 p. [in Ukrainian].

Yena, A. V. (2013). Introduktsiia ukrainskykh troiand. Introduktsiia roslyn, 2, 101-102. [in Ukrainian].

\section{И. А. Ковальчук, О. И. Скакальская, Я. А. Гетьман}

Кременеикий ботанический сад, г. Кременеи, Украина

\section{АСПЕКТЫ ИНТРОДУКЦИИ ПРЕДСТАВИТЕЛЕЙ РОДА ROSA L. В КРЕМЕНЕЦКОМ БОТАНИЧЕСКОМ САДУ}

Одним из важных направлений научно-исследовательских работ в области интродукции растений является создание, изучение, обогащение и сохранение генофонда растительного царства. Виды и сорта рода Rosa издавна привлекают внимание исследователей благодаря их широкому использованию в декоративном садоводстве и промышленном цветоводстве. Представлены результаты по интродукции представителей рода Rosa в Украине. Коллекция роз Кременецкого ботаническо- 
го сада по состоянию на 2017 г. насчитывает 28 сортов, входящих в 5 садовых групп (чайно-гибридные, миниатюрные, парковые, выющиеся, флорибунда). Интродукционное изучение проведено с учетом эколого-биологических и декоративных особенностей роз. По абиотическим экологическим факторам сорта роз относятся к факультативным гелиофитам, мезоксерофитам, мезотрофам. Согласно распределению сортов по садовым группам больше в коллекции представлены сорта роз, относящихся к чайно-гибридным - 10 видов (35,7 \%) от всей коллекции, самая малочисленная группа парковых - $1(3,5 \%)$. Проведенные фенологические наблюдения в период с 2012 по 2016 гг. за 28 видами, которые растут на коллекционном участке ботанического сада, позволили установить, что подавляющее большинство видов, представленных в коллекции, цветут и плодоносят ежегодно.

Ключевые слова: интродукция; сорт, роза; ботанический сад; Rosa L.

I. O. Kovalchuk, O. I. Skakal's'ka, Ya. A. Getman

Kremenets Botanical Garden, Kremenets, Ukraine

\section{ASPECTS OF AN INTRODUKTION OF REPRESENTATIVES OF THE GENUS ROSA L. IN THE KREMENETSKY BOTANICAL GARDEN}

One of the important directions of research works in the field of an introduction of plants is creation, studying, enrichment and preservation of a gene pool of a floral kingdom. Species and cultivars of the genus Rosa long since draw attention of researchers thanks to their wide use in decorative gardening and industrial floriculture. Results on an introduction of representatives of the genus Rosa in Ukraine are presented in article. The collection of roses of the Kremenetsky botanical garden on 2017 totals 28 grades entering into 5 garden groups (tea hybrid, tiny, park, long-stemmed, floribunda). Introduction of studying it was carried out taking into account ecological and biological and decorative features of roses. On abiotic ecological factors of a cultivars of roses belong to facultative geliofita, mesokserophita, mesophites. According to distribution of cultivar behind garden groups more cultivars of the roses relating to the tea hybrid are represented in a collection - 10 species $(35,7 \%)$ of all collection, the smallest group park - $1(3,5$ $\%)$. Grouping kinds after the terms of beginning and end of vegetation and flowering, it is marked by us, that after beginning of vegetation the sorts of roses belong to the group early spring - $100 \%$, duration of vegetation: to the group of long-hauling - $100 \%$, sometimes flowering is prevailed by a group late afternoon $-43 \%$, duration of flowering middleweight $-96,5 \%$. Grouping the types of roses it is possible to create the garden of their continuous flowering in a period from May for August month. Entered first-ever into the phase of dying off on October, 20 - 'Veilchenblau', 'Ledy gay', 'Sophia of loren', later in all on November, 7 - 'Wartburg', 'Landora' and other.The phenological observations made by us during the period from 2012 to 2016 behind 28 species which grow on a collection site of a botanical garden, allowed to establish that the vast majority of the species represented in a collection blossom and fructify annually.

Keywords: introduction; cultivar; rose; botanical garden; Rosa L. 